\title{
Effect of the outbreak of horse-chestnut leaf miner (Cameraria ohridella Deschka \& Dimić) on tree-ring width in common horse-chestnut (Aesculus hippocastanum L.)
}

Anna Cedro ( $\square$ anna.cedro@usz.edu.pl )

University of Szczecin: Uniwersytet Szczecinski https://orcid.org/0000-0002-7629-5840

Grzegorz Nowak

West Pomeranian University of Technology: Zachodniopomorski Uniwersytet Technologiczny w Szczecinie

\section{Research Article}

Keywords: tree-ring width (TRW), climate signal, dendroclimatology, dendrochronology, outbreak, invasive species, Cameraria ohridella (HCLM), Aesculus hippocastanum

Posted Date: April 28th, 2021

DOI: https://doi.org/10.21203/rs.3.rs-466202/v1

License: (c) (1) This work is licensed under a Creative Commons Attribution 4.0 International License.

Read Full License 


\section{Abstract}

Common horse-chestnut is frequently infested by the insect pest horse-chestnut leaf miner [HCLM; Cameraria ohridella (Deschka \& Dimić, 1986), Gracillariidae, Lepidoptera]. The larvae, feeding on leaf parenchyma, cause browning and dehydration of leaves, which may be shed as early as in summer. The major aims of this study were: (1) to assess the effect of infestation by HCLM on ring-width dynamics in common horse-chestnut; (2) to determine the date of invasion of the pest; and (3) to compare the growthclimate response in the period before and after the invasion of HCLM. In 2017 in north-western Poland, samples from 30 horse-chestnut trees for the dendrochronological analysis were taken with help of a Pressler increment borer. The ring-width chronology was developed using standard dendrochronological methods. Dendroclimatological analyses were made in 2 periods: before the determined date of HCLM invasion (till the year 1999) and after the invasion (in 20002016). In 2000, in spite of favourable weather conditions, a reduced growth rate was observed in $91 \%$ of the analysed trees. The period of strong reductions lasted till 2010. Before the invasion, radial growth rate was dependent on temperature and precipitation in May and June of the current year, whereas after the invasion, the growth-climate response was dependent on temperature and precipitation in the preceding year and the correlation was stronger. Surprisingly, in recent years (2011-2016), in spite of infestation by HCLM every year, the health condition of the analysed trees has improved and tree-ring width has increased.

\section{Introduction}

Common horse-chestnut (Aesculus hippocastanum L.) was introduced to Poland nearly 400 years ago. It was then, and still is, planted in gardens near palaces and in urban areas: along streets, in tree lines, parks, and in housing estates (Seneta 1991; Seneta and Dolatowski 2004; Spasić et al. 2011).

Until recently, horse-chestnut trees were rarely affected by diseases and pests. However, for a few decades in Europe we have observed an increase in frequency of Guignardia leaf blotch, caused by the fungus Guignardia aesculi, accidentally introduced from North America (Jagiełło et al. 2017). The first symptoms of tree infection are light brown patches on leaves, and the leaves are getting smaller and smaller every year (Raimondo et al. 2003). After a few years the tree dies (Madej 1971; Gilbert et al. 2004; Baraniak et al. 2005, Snieškienè 2011; Baranowski and Dankowska 2012; Dzięgielewska et al. 2017). This tree species in recent years has been also attacked by the insect pest horse-chestnut leaf miner [HCLM, Cameraria ohridella (Deschka \& Dimić, 1986), Gracillariidae, Lepidoptera]. Larvae of this moth feed on leaf parenchyma, leading to rusty discoloration and dehydration of leaves (which may be shed already in mid-July), and gradual dieback of branches (Thalmann et al. 2003; Jagiełto et al. 2017). HCLM invasion was first observed in Europe in 1984, when it was recorded near Lake Ohrid in Macedonia (Deschka and Dimić 1986). The species has spread to most of European countries, migrating at a rate of about $60 \mathrm{~km} /$ year. It was recorded in Spain and France in 2000, in England after crossing the English Channel in 2002, whereas in Denmark, Ukraine, and Sweden in 2003 (Gilbert et al. 2005). In Poland this species was first reported in 1998 near Wrocław (south-western part of the country). The pest quickly 
spread in the south of Poland, next it was found in Warsaw, Puławy, and Poznań (central Poland), but now it is widespread in our country (Głowacka et al. 2009).

The expansion of HCLM, which threatens the survival of common horse-chestnut in Europe, is associated with a complex of factors resulting mostly from human impact on the environment. The most important factors are: climate change (causing thermal and water stress), soil salinity, and pollution associated e.g. with road traffic, but also dispersal of the moths and leaves with larvae by wind as well as road and sea transport, which is facilitated by e.g. open borders and a lack of detailed control of vehicles and goods. The trees growing along major transportation routes are colonized first and next the pest is dispersed by people, animals, wind, and vehicles onto other trees (Głowacka et al. 2009). Container ports in West Europe are currently also a threat, as goods are transported from them in virtually all directions, and trees in those cities are infested by HCLM (Gilbert et al. 2005). Simultaneously, to save trees of this species, research was started (e.g. Percival and Holmes 2016) as well as many institutional measures (e.g. spraying with insecticides, injection of insecticides into the trunk or the soil, or placing of bands with specific pheromones on their trunks) and voluntary actions (e.g. raking of leaf litter).

Adult individuals of HCLM are very small moths, with body length reaching 3-4 $\mathrm{mm}$ and wing span of only 5-8 mm (Jaworski 2009). During emergence they are abundant on horse-chestnut trunks. Currently their density is so high that in one leaf up to 300 of its larvae can be observed, forming mines (empty corridors, devoid of parenchyma). Feeding on horse-chestnut leaves lasts from May till September, and up to $98 \%$ of photosynthetic area can be lost due to this (Percival et al. 2011), as the moths reduce the green, photosynthetic area of leaves and cause their earlier drying and shedding (Nardini et al. 2004). Moreover, seed weight is lower, and also the affected seedlings are weaker (Takos et al. 2008).

Dendrochronology is one of the methods used for reconstruction of environmental conditions (Schweingruber 1996). Tree-ring width curves reflect primarily the weather conditions (which are the most variable environmental factors), but also changes in groundwater level, the level of pollution, fires, management practices, construction works near the trees, pest outbreaks, etc. (Schweingruber 2007; Koprowski et al. 2018). Invasions of pests cause depressions of growth (or even absence of some treerings), pale late wood, multiple rings of traumatic resin canals, etc. (Koprowski and Duncker 2012; Lynch 2012; Leland et al. 2016). If no direct long-term observations of individual trees or forest stands are available, then dendrochronological methods make it possible to reconstruct with a high precision the timing of extreme events (Koprowski and Duncker 2012; Zhang 2015).

The major aims of this study were: (1) to assess the effect of infestation by HCLM on ring-width dynamics in common horse-chestnut; (2) to determine the date of invasion of the pest; and (3) to compare the growth-climate response in the period before and after the invasion of HCLM. We also assessed tree health in the investigated avenue as well as the activity and damages caused by HCLM. We hypothesized that the invasion of HCLM lowered the dynamics of horse-chestnut tree-ring width and that the growth-climate response differed between the periods before and after the invasion of HCLM. 


\section{Materials And Methods}

Field research was conducted in 2017 on common horse-chestnut trees (Aesculus hippocastanum L.), growing along a 400-m section of a public road in a village of Buk in Dobra Commune in West Pomerania Province. The trees were planted on both sides of the road, forming an avenue (Fig. 1). The study area is located in NW Poland, $12 \mathrm{~km}$ from Szczecin, about $400 \mathrm{~m}$ from the German border. The climate of Szczecin is predominantly influenced by the polar-sea air masses from the North Atlantic, and also affected by local circulation from the South Baltic and the water bodies surrounding the city. The average annual temperature in $1948-2016$ was $+8.7^{\circ} \mathrm{C}$, but the average temperature in the warmest years reached $+10.9^{\circ} \mathrm{C}$, compared to $+7.1^{\circ} \mathrm{C}$ in the coolest years. The warmest month is July, with the average temperature of $+18.1^{\circ} \mathrm{C}$ (varying between years: $15.2-22.7^{\circ} \mathrm{C}$ ), and the coolest is January, with the average air temperature of $-0.4^{\circ} \mathrm{C}$ (range: $-8.8-5.1^{\circ} \mathrm{C}$ ). Thus the average annual amplitude equals to $18.5^{\circ} \mathrm{C}$. The average annual rainfall for the city of Szczecin amounts to $545 \mathrm{~mm}$ (range: $347-796 \mathrm{~mm}$ ). The most humid month is usually July, with $71 \mathrm{~mm}$ of average rainfall (but varying between years: 5-185 $\mathrm{mm}$ ), whereas the driest one is February, with the average rainfall amounting to $31 \mathrm{~mm}$ (range: $3-77$ $\mathrm{mm}$ ) (Meteorological Yearbooks). According to Heinz and Schreiber's (1987) division into climatic zones and subzones, the area is in subzone $7 \mathrm{a}$, with mean long-term minimum temperature from $-17.7^{\circ} \mathrm{C}$ to $-15.0^{\circ} \mathrm{C}$.

The infested leaf area was assessed on the basis of the percentage contribution of the injured part of the leaf to the total leaf area. For this purpose, symptoms of HCLM infestation were recorded throughout the growing season of 2017 (every 2 weeks, from early May to late September), and in mid-August 20 leaves from 30 trees were randomly collected from the lower part of each tree crown and mean values were calculated.

The trees grow about $1 \mathrm{~m}$ from the road edge, spaced about $10 \mathrm{~m}$ apart. This avenue was selected because of preservation of its design, absence of protective measures, and lack of removal of tree leaves, which could influence the development of trees and HCLM.

Samples from 30 common horse-chestnut trees for the dendrochronological analysis were taken with the help of a Pressler increment borer at breast height (1.3 m above ground) in April 2017. In the laboratory, the cores sampled were glued into wooden mounts, and after drying, their surfaces were cut with a preparation knife to get legible images of growth rings. The measurements of the annual tree-ring widths (TRW), with $0.01 \mathrm{~mm}$ accuracy, were made using the Dendrometer program (Mindur 2000), starting from the innermost parts, towards the bark. Altogether 3274 annual growth rings were measured. Then, using the classic method of dendrochronological dating (cross-dating) (Cook and Kairiukstis 1992; Schweingruber 1989), a ring-width chronology was constructed, and its quality was tested with the COFECHA program, from the DPL package (Holmes 1983, 1994; Grissino-Mayer 2001). The constructed RES chronology (de-trended, autocorrelation removed) was subjected to indexation (using a negative exponential curve and autoregressive modelling), to eliminate the age trend and to emphasize the annual variability of the annual growth ring widths, in the ARSTAN program (Cook and Holmes 1999). An 
expressed population signal (EPS) of $\geq 0.85$ was used to ensure a reliable chronology length (Wigley et al. 1984).

Our dendroclimatological analyses encompassed an analysis of the signature years, correlation, and response function. The signature years are the years in which a majority of the trees examined demonstrate the same incremental trends: increase of TRW with respect to the neighbouring years (positive signature year, marked as + ) or decrease in increment width (negative year, marked as -) (Meyer 1997-1998). The signature years were calculated from a minimum of 10 trees, assuming the minimum threshold of unanimity of the incremental reactions at $95 \%$. In the analysis of the correlation and response function, the RES tree-ring index chronology was compared with meteorological data from a weather station situated $12 \mathrm{~km}$ SE from the plot investigated. The values of monthly average air temperatures $(T)$ and total monthly precipitation $(P)$ were analysed for the period of 69 years (19482016), whereas insolation (IN), for the period of 52 years (1965-2016) (Meteorological Yearbooks). The analyses of correlation and response function were made in 2 periods: before the determined date of HCLM invasion (till 1999) and after the invasion (2000-2016). For every year in which an annual growth ring was formed, its width was confronted with meteorological data for the period of 16 months: from June of the year preceding growth (pJUN) till September of the current growth year (SEP). In every case the multiple regression coefficient of determination $\left(r^{2}\right)$ was calculated, determining the strength of the relationship between the features analysed (RESPO program from the DPL package, Holmes 1994).

Relative growth changes in plot chronology were detected using Nowacki and Abrams' (1997) method. Running comparisons of sequential 10-year ring-width means were used to detect periods of decrease and increase of TRW, while discounting short- and long-term climatic change and tree aging trend. Percentage growth change (\%GC) was calculated in yearly increments across individual tree-ring chronology by using the formula:

$\% G C=\left[\left(M_{2}-M_{1}\right) / M_{1}\right] \times 100$,

where $\mathrm{M}_{1}$ = preceding 10-year mean, and $\mathrm{M}_{2}$ = subsequent 10-year mean (Nowacki and Abrams 1997; Black and Abrams 2004; Läänelaid et al. 2014; Cedro and Sotek 2016).

\section{Results}

\section{Tree health}

In the study area, the first mines on common horse-chestnut leaves in 2017 were observed from mid-May. Since then, the mean area of mines in leaves regularly and markedly increased. Very strong infestation (up to $70-80 \%$ for most of the trees) was recorded already in the second half of August. This resulted in earlier shedding of leaves, started in late August. The decreasing amount of parenchyma and photosynthetic pigments in leaves markedly affected the physiological processes in the infested trees. 
The constructed chronology named BU, spanning 116 years (1901-2016), is based on ring-width curves of 22 trees (Fig. 2). The largest number of rings was measured for tree BU13, i.e. 136 rings from the innermost part to the bark, followed by 134 rings for BU3 and 132 for BU1. This indicates that the trees were about 145 years old, and the avenue was planted in the $1880 \mathrm{~s}$. Mean TRW was $3.54 \mathrm{~mm}$ (for individual trees: $2.22-4.31 \mathrm{~mm}$. The chronology can be regarded as representative, as the value of expressed population signal (EPS) is high: 0.92. The curves of ring widths and their indexed values do not indicate unambiguously the year of invasion of HCLM on the studied trees, so we used the curve of relative growth change to determine the date of invasion (Fig. 3). Relative growth changes show that tree growth rate increased in 1916-1929, 1939-1948, 1955-1974, 1980-1999, and at the end of the chronology, in 2011-2016, whereas it decreased in 1910-1915, 1930-1938, 1949-1954, 1975-1979, and 2000-2010. Considering the direction of the spread of HCLM (from Macedonia), and the first record of this folivore in Poland (Wrocław in 1998, Łabanowski and Soika 1998), we looked for reduction of ring width caused by HCLM after this date. The impact of HCLM infestation on horse-chestnut TRW in the avenue in Buk started in 2000 (Fig. 3). This is not the date of appearance of Cameraria ohridella on the studied trees but of noticeable (measureable) influence of HCLM infestation on tree-ring width.

\section{Dendroclimatology}

The analysis of signature years indicates 34 years when more than $95 \%$ trees showed consistent growth responses in relation to the preceding year. Negative pointer years prevailed (22): 1910, 1915, 1918, 1923, 1925, 1930, 1934, 1938, 1940, 1948, 1954, 1956, 1960, 1964, 1970, 1973, 1975, 1977, 1982, 1992, 1997, and 2010. Only 12 pointer years were positive: 1924, 1939, 1950, 1955, 1957, 1961, 1987, 1993, 2007, 2009,2011 , and 2013 . In 2000 , as many as $91 \%$ of the analysed trees produced narrower growth rings than in the preceding year. Positive pointer years were characterized by higher precipitation than the longterm mean, with sufficient rainfall (or snowfall) in spring and summer (especially in June), whereas the number of sun hours was lower than the long-term mean. Negative pointer years usually were preceded by years with water shortages, and also during the pointer years the recorded precipitation was lower than average. Low precipitation in May, June or July, linked with high air temperature and strong insolation, were the major causes of negative pointer years.

In the year 2000, weather conditions were favourable for horse-chestnuts. Mean annual air temperature in $2000\left(9.9^{\circ} \mathrm{C}\right)$ was $1.2^{\circ} \mathrm{C}$ higher than the long-term mean $\left(8.7^{\circ} \mathrm{C}\right)$, while annual precipitation $(572 \mathrm{~mm})$ was nearly $30 \mathrm{~mm}$ higher than the long-term mean $(545 \mathrm{~mm})$, and the number of sun hours (1612 h) was slightly higher than the long-term mean $(1588 \mathrm{~h})$. Summer months of that year were colder, with higher precipitation and lower insolation than long-term means. Only April and May in 2000 were warmer, more sunny, and drier than long-term means (Fig. 4). In that year, no renovation of the road and the associated infrastructure took place, which could have affected negatively the root systems of trees, and consequently also tree health in general (oral communication in the Commune Office). In 2000-2005, the curve of relative growth change shows that tree-ring width was reduced by $70 \%$ and stayed low till 2010 . Starting from 2011, however, in spite of the presence of HCLM and early defoliation of the trees every year, relative growth change increased by $50 \%$ (Fig. 3). Positive pointer years after the date of HCLM 
invasion were recorded in $2007,2009,2011$, and 2013. In all those years, mean annual precipitation was higher than average (the year 2007 was the wettest during the study period, with annual precipitation of $796 \mathrm{~mm}$ ) and high rainfall was observed in summer months (June and July), e.g. $185 \mathrm{~mm}$ in July 2011 (compared to the long-term mean of $71 \mathrm{~mm}$ for this month) and $141 \mathrm{~mm}$ in June 2013 (compared to the long-term mean of $60 \mathrm{~mm}$ ). The negative pointer year 2010 was characterized by low precipitation in June-July.

The analyses of correlation and response function made for the period before the invasion (1948-1999), and after the invasion (2000-2016) of HCLM showed different growth-climate responses (Fig. 5). Before the invasion, tree-ring width was affected predominantly by weather conditions in May and June. Lower than average air temperature, lower number of sun hours, and higher precipitation contributed to formation of broader tree-rings. In the year preceding growth, few relationships were observed (in September, October, and December). The highest multiple regression coefficient of determination was calculated for insolation (45\%), lower for precipitation (38\%), and the lowest for temperature (26\%). After the invasion of HCLM (2000-2016), similar relationships were found for precipitation in June of the current year, whereas in July the regression coefficient was negative. However, the greatest changes can be noticed in the year preceding growth and in winter: values of correlation and regression are usually positive for precipitation and negative for temperature and insolation. A cold, clouded, and moist previous growing season as well as frosty and clouded winter contributed to formation of broader tree-rings. For each of the analysed climatic factors, $r^{2}$ increased, which indicates very strong growth-climate relations. For insolation it reached $83 \%$, for air temperature $74 \%$, and for precipitation $40 \%$.

\section{Discussion}

The spread of HCLM across Europe has been noticed by its inhabitants. HCLM infestation of horsechestnut trees - present in most of European countries for several hundred years, planted in parks, gardens, and avenues as ornamentals - has been widely discussed in the mass media. The rapid spread of HCLM is facilitated by the modern lifestyle and technological progress: frequent travels, a lack or limited border control, and heavy road traffic (Łabanowski and Soika 1998; Gilbert et al. 2004; Baraniak et al. 2005; Kosibowicz 2005; Głowacka et al. 2009; Snieškienè 2011).

Another contributing factor is the observed climate change, causing extension of the potential range of distribution of this pest. Over the past three decades, HCLM has spread throughout Europe - even crossing mountain barriers, seas and canals - it has even been observed in England, Denmark and Sweden in the early 2000s, thousands of kilometers from its first sighting in 1984 at Lake Ohrid in Macedonia (Gilbert 2005). Because of the disturbance of the life cycle, the trees do not initiate the normal winter dormancy and are prone to frost damage, especially if winter starts early and is more severe. Repeated infection of trees for a few years leads to their weakening (Percival et al. 2011), leading to e.g. lower growth dynamics and formation of narrower tree-rings. The rate of development of individual stages of the HCLM life cycle depends on insolation and temperature. Probably high insolation and high temperature in summer stimulate females to lay eggs faster (Jäckel et al. 2006; Bystrowski et al. 2008). 
That is why a change in the growth-climate response during the HCLM outbreak was observed after the year 2002, i.e. it started to be more dependent on conditions in the year preceding growth and the strength of the dependence increased, especially for temperature (from $26 \%$ before the invasion to $74 \%$ after the invasion) and insolation (from $45 \%$ to $83 \%$ ). Lower than average air temperature, lower number of sun hours, and higher precipitation at the end of the preceding year negatively affect the last stages of the HCLM life cycle, which results in a smaller number of overwintering parasitoids and weaker infestation in the following year (Samek 2003). After such a pattern of weather conditions, trees in the following growing season are healthier and develop wider growth rings.

Common horse-chestnut is rarely studied by dendrochronologists. In Slovenia its radial growth depends on moisture conditions (precipitation-evapotranspiration index, SPEI) in summer months: June-August, as droughts cause strong reductions of tree-ring width (Simon and Lena 2016). In Poland similar research was conducted by Wilczyński and Podlaski (2007), but effects of HCLM infestation on tree-ring width were studied only by Bednarz and Scheffler (2008). According to Wilczyński and Podlaski (2007), radial growth rate of this species in mountainous regions is affected most significantly by temperatures in winter (December-March) and August as well as precipitation in December in the year preceding growth. High temperatures in those months and high precipitation in December result in formation of broad treerings. Horse-chestnuts growing in urban areas (Kraków, southern Poland) are sensitive to weather conditions in the year preceding growth: correlation coefficients were negative for temperatures in July, August, and September, while positive for precipitation in August of the preceding year and June of the current year (Bednarz and Scheffler 2008). The HCLM outbreak in Kraków probably started in 1997, which was followed by strong growth reductions, lasting till 2005. Those results are consistent with our data from north-western Poland (horse-chestnut avenue in the village of Buk). Although the outbreak started here 5 years later (our study area is located about $700 \mathrm{~km}$ NW of Kraków), the growth response of trees and growth-climate relations indicate that weather conditions in the preceding year were the dominant factors shaping the growth dynamics. Research conducted by Salleo et al. (2003) shows a different response of common horse-chestnuts to HCLM infestation: they reported an increased number of false rings, an increase in tree-ring width, and an increase in hydraulic efficiency of wood for 4 years after the invasion (which probably started in north-eastern Italy in 1997).

Besides, the recently recorded (2011-2016) increase in radial growth dynamics of the studied trees, in spite of HCLM infestation every year, suggests that the infested trees have developed a defence strategy (Łabanowski and Soika 1998; Malinowski 2008; Baranowski and Dankowska 2012). This issue has not been studied yet, but the appearance of defence mechanisms in the studied trees seems to be evidenced by an increase in their vitality: many young boughs with uninfested or less infested leaves, intensive scarring of wounds, intensive flowering and fruiting, broader tree-rings, as compared with previous years. Moreover, natural parasites of HCLM appear (e.g. Minotetrastrichus frotalis), which infest this pest, but its infestation rate is lower than those of other species of leaf miners (Bystrowski et al. 2008).

\section{Conclusions}


At the time of climate change and strong increase in human impact, and the resultant spread of invasive species, it is necessary to study species that are prone to infestation by pests that did not inhabit a given region earlier. Horse-chestnut trees, although they have been intentionally introduced to many parts of Europe, are now familiar and valuable elements of our landscape. The large numbers of dying horsechestnut trees or the remarkable deterioration of the condition of this species, observed in recent years mostly due to the HCLM invasion, is subject not only of scientific research but also of public discussions. That is why research on the growth-climate relations in the period before the HCLM invasion and during the invasion is an important contribution to current knowledge about species attacked by pathogens and invasive species. Results of this study can also contribute to development of a strategy of conduct during invasion of new alien pests.

Our most interesting finding is the improved tree health in the last few years, in spite of infestation by HCLM. The increased tree-ring width, large number of young branches, or wound healing can indicate that the trees have developed some natural defence mechanisms and/or some parasites have attacked the invaders. Research on these mechanisms as well as mutual relationships (tree - invasive pest - its parasite - climate change) may help us control pest outbreaks and epidemics in the future, as in the case of e.g. the already spreading box tree moth (Cydalima perspectalis) or the fungus causing anthracnose on London plane (Gnomonia platani).

\section{Declarations}

Author Contributions: A.C., G.N. conceptualization; field collection, data analyses, draft preparation, review and editing. All authors have read and agreed to the published version of the manuscript.

Funding: The authors did not receive support from any organization for the submitted work.

Employment: A.C. University of Szczecin, G.N. West Pomeranian University of Technology in Szczecin

Financial interests: The authors have no financial or proprietary interests in any material discussed in this article.

Data Availability Statement: The datasets generated during and/or analysed during the current study are available from the corresponding author on reasonable request. The data presented in this study will be available after positive decisions in REpOD (Repository for Open Data, https://repod.icm.edu.pl/, with DOI).

Conflicts of Interest: The authors declare no conflicts of interest.

\section{References}

Baraniak E, Walczak U, Zduniak P. 2005. Appearance and migration of the horse-chestnut leafminer Cameraria ohridella in relations to city size and leaf-raking, using the example of two cities in Western 
Poland. Journal of Pest Science, 78(3), 145-149. https://doi.org/10.1007/s10340-005-0085-6

Baranowski T, Dankowska E. 2012. The integrated protection of horse-chestnuts against horse chestnut leafminer (Cameraria ohridella Deschka \& Dimić). Progress in Plant Protection (4) 2012, 807-810.

Bednarz B, Scheffler M. 2008. Wpływ żeru szrotówka kasztanowcowiaczka (Cameraria ohridella Deschka \& Dimić) na szerokość słojów rocznych kasztanowca białego (Aesculus hippocastanum L.). [Effect of horse chestnut leaf-miner (Cameraria ohridella Deschka \& Dimić) outbreak on tree-ring width of white horse-chestnut (Aesculus hippocastanum L.)]. Sylwan 7, 53-66.

Black BA, Abrams MD. 2004. Development and application of boundary-line release criteria. Dendrochronologia 22, 31-42. DOI: 10.1016/j.dendro.2004.09.004

Bystrowski C, Celmer-Warda K, Tarwacki G. 2008. Effects of horse chestnut (Aesculus hippocastanum L.) site on horse chestnut leaf-miner (Cameraria ohridella Deschka et Dimić) parazytoids appearance and number in Central Poland. Forest Research Papers 69 (1), 49-55.

Cedro A, Sotek Z. 2016. Natural and anthropogenic transformations of a Baltic raised bog (Bagno Kusowo, north west Poland) in the light of dendrochronological analysis of Pinus sylvestris L. Forests 7(9), 202. DOI:10.3390/f7090202.

Cook ER, Holmes RL. 1999. Program ARSTAN - Chronology development with statistical analysis (User manual for program ARSTAN). Laboratory of Tree-Ring Research, University of Arizona, Tuscon, 18.

Cook ER, Kairiukstis A. 1992. Methods of dendrochronology. Kluwer Academic Publishers, 394.

Deschka G, Dimič N. 1986. Cameraria ohridella n. sp. Aus Mazedonien, Jugoslawien (Lepidoptera, Lithocolletidae). Acta Entomologia Jugoslavia 22, 11-23.

Dzięgielewska M, Adamska I, Mikiciuk M, Nowak G, Ptak P. 2017. Effects of biotic and abiotic factors on the health of horse chestnut trees in an urban area of north-western Poland. Ecological Questions 27, 3, 25-38.

Gilbert M, Grégoire J-C, Freise JF, Heitland W. 2004. Long-distance dispersal and human population density allow the prediction of invasive patterns in the horse chestnut leafminer Cameraria ohridella. Journal of Animal Ecology, 73(3), 459-468. https://doi.org/10.1111/j.0021-8790.2004.00820.x

Gilbert M, Guichard S, Freise J, Grégoire JC, Heitland W, Straw N, Tilbury C, Ugustin SA. 2005. Forecasting Cameraria ohridella invasion dynamics in recently invaded countries: from validation to prediction. Journal of Applied Ecology 42, 805-813. DOI: 10.1111/j.1365-2664.2005.01074.x.

Głowacka B, Lipiński S, Tarwacki G. 2009. Possibilities of protection of the horse-chestnut Aesculus hippocastanum $\mathrm{L}$. against the horse chestnut leaf-miner Cameraria ohridella Deschka et Dimic. Forest Research Papers 70 (4), 317-328. https://doi.org/10.2478/v10111-009-0030-1. 
Grissino-Mayer HD. 2001. Evaluating crossdating accuracy: a manual and tutorial for the computer program COFECHA. Tree-Ring Research 57, 205-221.

Heinze W, Schreiber D. 1987. Eine neue Kartierung der Winterhärtezonen für Gehölze in Europa. Mitt. D. Deutsch. Dendrol. Ges. 75, 11-56.

Holmes RJ. 1983. Computer-assisted quality control in tree-ring dating and measurement. Tree-Ring Bulletin 43, 69-78.

Holmes RJ. 1994. Dendrochronology Program Library. Users Manual. University of Arizona, Tucson.

Jagiełło R, Baraniak E, Karolewski P, Łakomy P, Behnke-Borowczyk J, Walczak U, Giertych MJ. 2017. Ecophysiological aspects of the interaction between Cameraria ohridella and Guignardia aesculi on Aesculus hippocastanum. Dendrobiology 78,146-156.

Jaworski T. 2009. Lime leafminer Phyllonorycter issikii (Kumata, 1963) (Lepidoptera, Gracillariidae) in Poland. Forest Research Papers 70 (1), 89-91.

Jäckel B, Balder H, Grabenweger G, Hopp H, Koch T, Schmolling S. 2006. Standortbhängiges Parasitierungsverhalten von Gegenspielern der Roßkastanienminiermotte (Cameraria ohridella) in Berlin. Mitt.Dtsch. Ges. Allg. Angew. Ent., 15, 81-84.

Koprowski M, Duncker P. 2012. Tree ring width and wood density as the indicators of climatic factors and insect outbreaks affecting spruce growth. Ecological Indicators 23, 332-337. https://doi.org/10.1016/j.ecolind.2012.04.007.

Koprowski M, Okoński B, Gričar J, Puchałka R. 2018. Streamflow as an ecological factor influencing radial growth of European ash (Fraxinus excelsior (L.)). Ecological Indicators 85, 390-399. https://doi.org/10.1016/j.ecolind.2017.09.051.

Kosibowicz M. 2005. Szrotówek kasztanowcowiaczek Cameraria ohridella Deschka \& Dimić (Lepidoptera, Gracillariidae), nowy inwazyjny szkodnik kasztanowca białego Aesculus hippocastanum L. w Polsce biologia i metody zwalczania [The horse chestnut leaf miner Cameraria ohridella Deschk \& Dimić (Lepidoptera, Gracillariidae), as a new invasive pest of Aesculus hippocastanum L. in Poland - biology and control methods]. Leśne Prace Badawcze, 2005/2, 121-132.

Läänelaid A, Sohar K, Kull A. 2014. Kuivenduse möju ulatus Tellissaane rabas mändide jämeduskasvu järgi. In: Tammiksaar E, Pae T, Mander Ü (ed) 95 Years of Estonian Geography: Selected Studies. Tartu, 219-229.

Leland C, Hom J, Skowronski N, Ledig FT, Krusic PJ, Cook ER, Martin-Benito D, Martin-Fernandez J, Pederson N. 2016. Missing Rings, Synchronous Growth, and Ecological Disturbance in a 36-Year Pitch Pine (Pinus rigida) Provenance Study. PLoS One 11(5), e0154730. doi: 10.1371/journal.pone.0154730 
Lynch AM. 2012. What tree-ring reconstruction tells us about conifer defoliator outbreaks. In: Insect outbreaks revisited, First Edition. Edited by Pedro Barbosa, Deborah K. Letourneau and Anurag A. Agrawal. Blackwell Publishing Ltd., 126-155.

Łabanowski G, Soika G. 1998. Szrotówek kasztanowcowiaczek zagraża kasztanowcom w Polsce [The horse chestnut leafminer infesting chestnut in Poland]. Ochrona Roślin. 42(12), 12.

Madej T. 1971. Mikoflora drzew i krzewów ogrodu dendrologicznego w Przelewicach (woj. szczecińskie) [Mycoflora of trees and shrubs in the dendrological garden in Przelewice (szczecińskie woivodship)], Fragmenta Floristica et Geobotanica 17, 583-600.

Malinowski H. 2008. Defensive strategies of woody plants against harmful insects. Forest Research Papers 69, 165-173.

Meteorological Yearbooks, 1948-1998. (Roczniki Meteorologiczne IMGW, 1948-1998).

Meyer FD. 1997-1998. Pointer years analysis in dendrochronology: a comparison of methods. Dendrochronologia 16-17, 193-204.

Mindur B. 2000. Dendrometer 1,0 (Dendrometer 1.0 Software). Kraków.

Nardini A, Raimondo F, Scimone M, Salleo S. 2004. Impact of the leaf miner Cameraria ohridella on whole-plant phytosynthetic productivity of Aesculus hippocastanum: insights from a model. Trees 18, 714-721. DOI: 10.1007/s00468-004-0358-3.

Nowacki GJ, Abrams MD. 1997. Radial-growth averaging criteria for reconstructing disturbance histories from presettlement-orgin oaks. Ecological Monographs 67(2), 225-249.

Percival GC, Barrow I, Noviss K, Keary I, Pennington P. 2011. The impact of horse chestnut leaf miner (Cameraria ohridella Deschka and Dimic; HCLM) on vitality, growth and reproduction of Aesculus hippocastanum L. Urban Forestry \& Urban Greening 10,11-17. DOI: 10.1016/j.ufug.2010.11.003.

Percival GC, Holmes SP. 2016. The influence of systemic inducing agents on horse chestnut leaf-miner (Cameraria ohridella) severity in white flowering horse-chestnut (Aesculus hippocastanum L.). Urban Forestry \& Urban Greening 20, 97-102. http://dx.doi.org/10.1016/j.ufug.2016.08.009.

Raimondo F, Ghirardella LA, Nardini A, Salleo S. 2003. Impact of the leafminer Cameraria ohridella on photosynthesis, water relations and hydraulic of Aesculus hippocastanum leaves. Trees 17, 376-382.

Samek T. 2003. Diapause of Cameraria ohridella Deschka et Dimic and its impact on the species population dynamics. Journal of Forest Science 49 (6), 252-258,

Salleo S, Nardini A, Raimondo F, Lo Gullo MA, Pace F, Giacomich P. 2003. Effects of defoliation caused by the leaf miner Cameraria ohridella on wood production and efficiency in Aesculus hippocastanum 
Growing in north-eastern Italy. Trees 17, 367-375. DOl: 10.1007/s00468-003-0247-1.

Seneta W. 1991. Drzewa i krzewy liściaste A-B. [Deciduous trees and shrubs A-B]. Wydawnictwo Naukowe PWN, Warszawa, 331.

Seneta W, Dolatowski J. 2004. Dendrologia [Dendrology]. Wydawnictwo Naukowe PWN, Warszawa, 559. Schweingruber FH. 1989. Tree rings: Basics and applications of dendrochronology. Kluwer Academic Publishers.

Schweingruber FH. 1996. Tree rings and environment: dendroecology. Haupt. Berne, Stuttgart, Vienna, 609 .

Schweingruber FH. 2007. Wood structure and environment. Springer Series in Wood Science. Springer, 279.

Simon P, Lena M. 2016. Radial growth response of horse-chestnut (Aesculus hippocastanum L.) trees to climate in Ljubljana, Slovenia. Urban Forestry \& Urban Greening 18, 110-116.

http://dx.doi.org/10.1016/j.ufug.2016.05.013.

Snieškienè V, Baležentienè L, Stankevičienè A. 2011. State of horse-chestnut, Aesculus hippocastanum L., in Lithuania: diseases and pest damages, Ekologija 57(2), 62-69.

Spasić T, Tomašević M, Rajšić S, Tasić M. 2011. Trace elements accumulation and temporal trends in leaves of urban deciduous trees (Aesculus hippocastanum and Tilia spp.). Ecological Indicators 11/3, 824-830. https://doi.org/10.1016/j.ecolind.2010.10.009

Takos I, Varsamis G, Avtzis D, Galatsidas Sp, Merou Th, Avtzis N. 2008. The effect of defoliation by Cameraria ohridella Deschka and Dimic (Lepidoptera: Gracillariidae) on seed germination and seedling vitality in Aesculus hippocastanum L. Forest Ecology and Management 255, 830-835.

Thalmann C, Freise J, Heitland W, Bacher S. 2003. Effects of defoliation by horse chestnut leaf miner Cameraria ohridella on reproduction in Aesculus hippocastanum. Trees 17, 383-388.

Wigley TML, Briffa KR, Jones PD. 1984. On the average value of correlated time series, with applications in dendroclimatology and hydrometeorology. Journal of Climate and Applied Meteorology 23, 201-213.

Wilczyński S, Podlaski R. 2007. The effect of climate on radial growth of horse-chestnut (Aesculus hippocastanum L.) in the Świętokrzyski National Park in central Poland. J For Res 12, 24-33. DOI: 10.1007/s10310-006-0246-3.

Zhang Z. 2015. Tree-rings, a key ecological indicator of environment and climate change. Ecological Indicators 51, 107-116.

https://doi.org/10.1016/j.ecolind.2014.07.042 


\section{Figures}

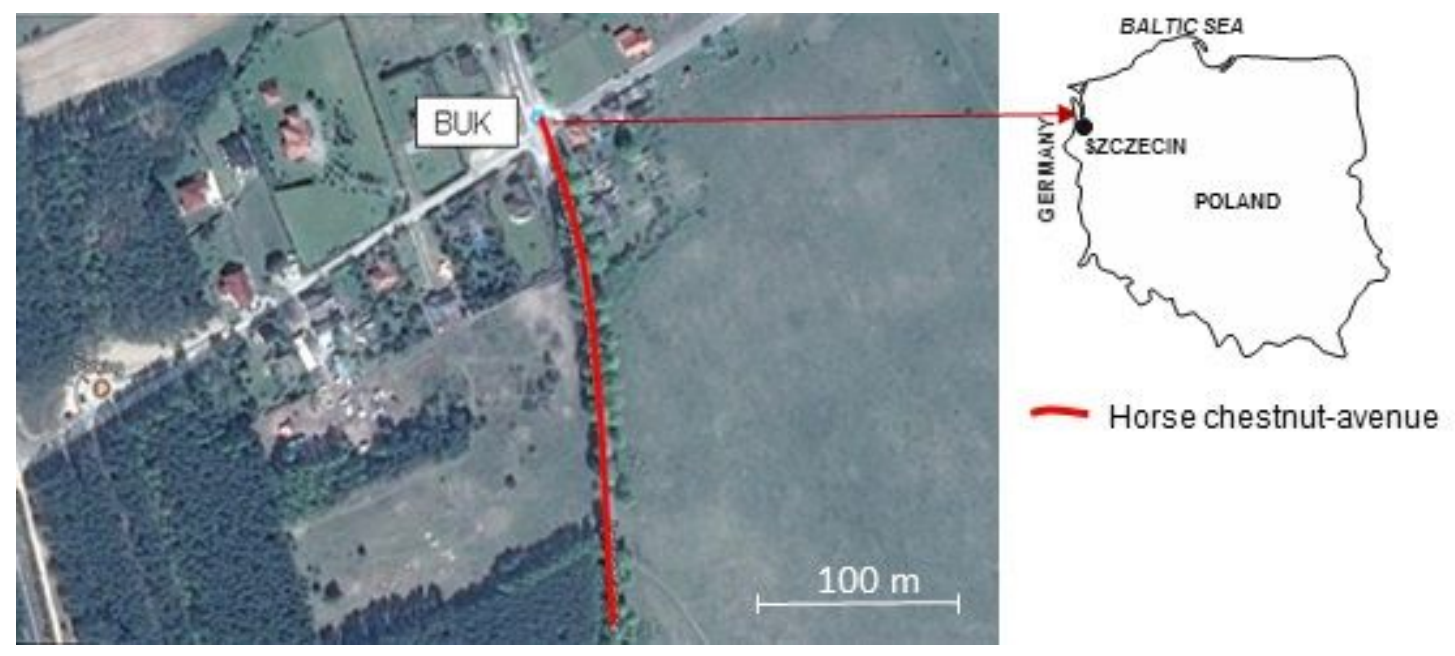

\section{Figure 1}

Location of the study area. (source of the map: www.geoportal.gov.pl)

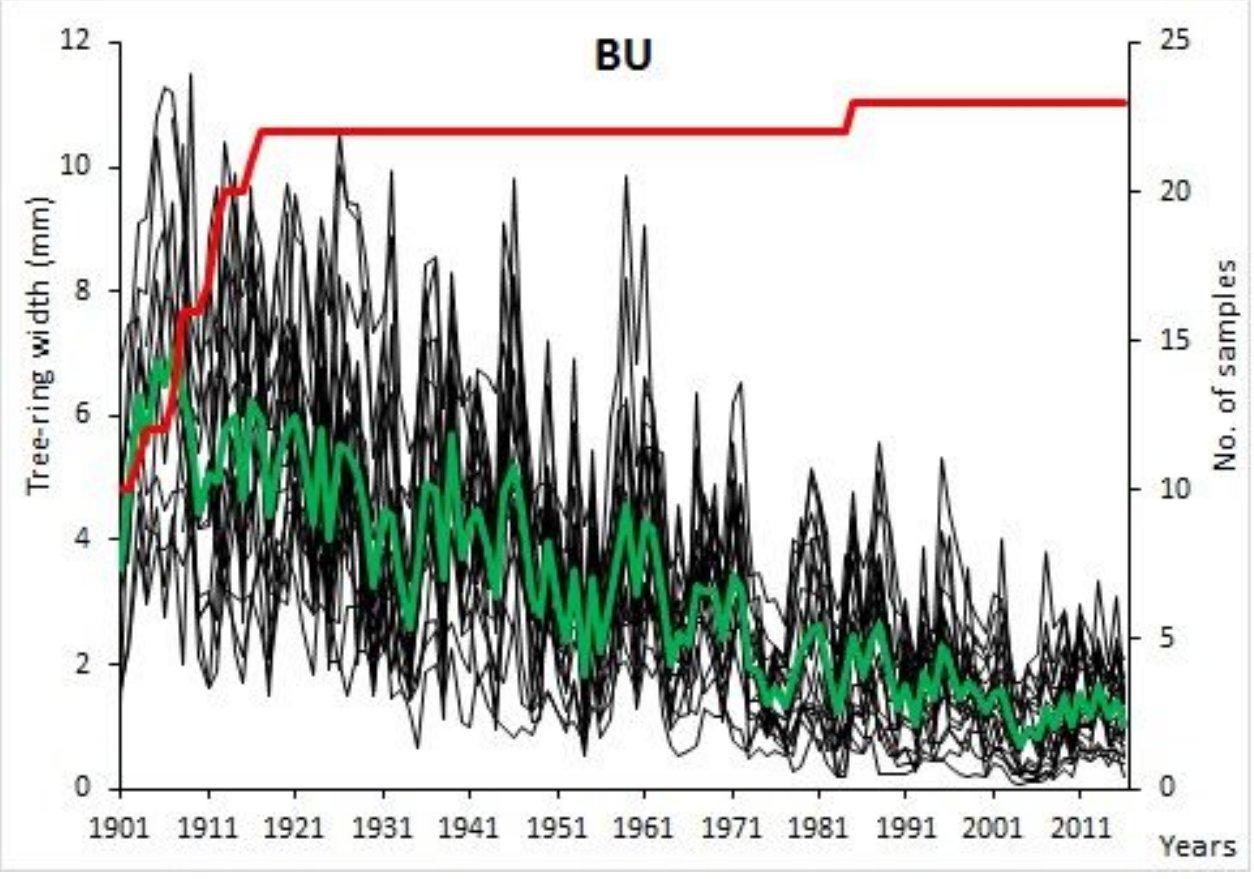

Figure 2

Individual sequences of tree-ring width (thin black lines), making up the local horse-chestnut chronology (BU; green line), and number of samples in the chronology (red line). 


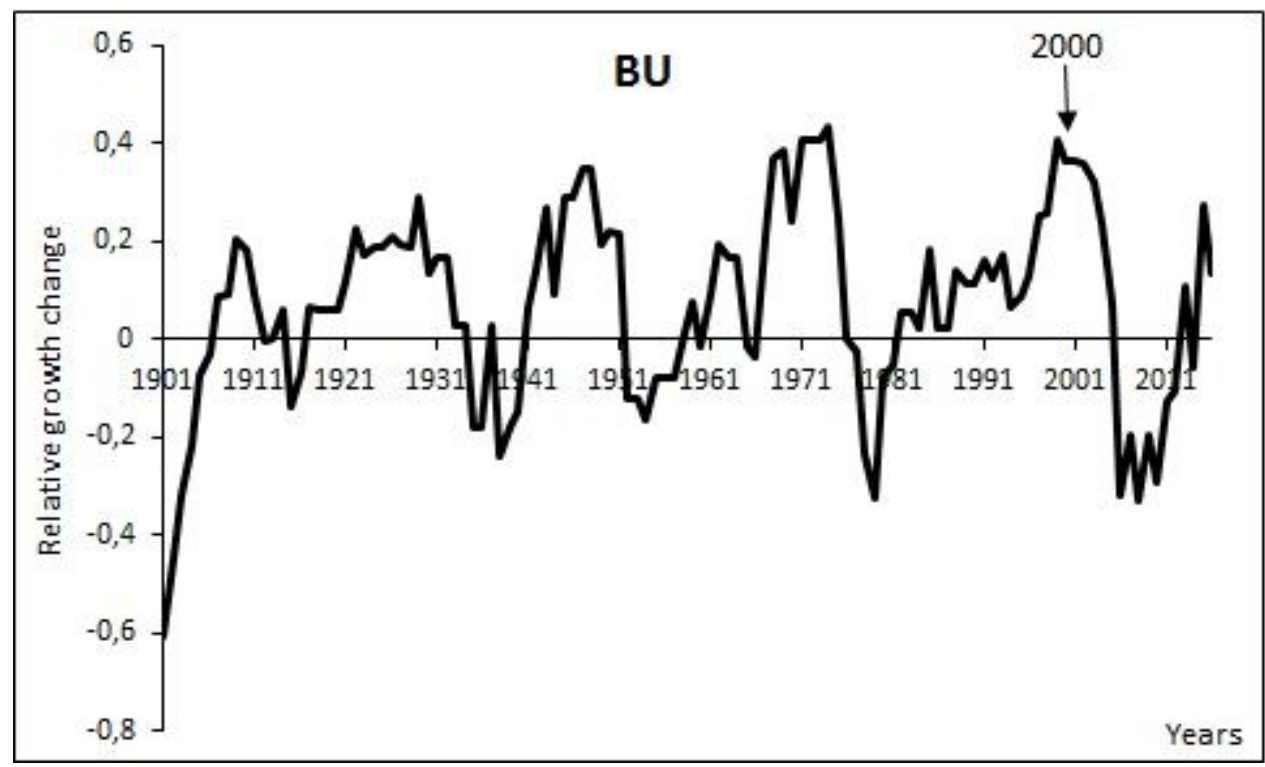

Figure 3

Running relative growth change of the horse-chestnut chronology (BU), showing the relative growth change between mean tree-ring width of 10 preceding and mean of 10 subsequent years.

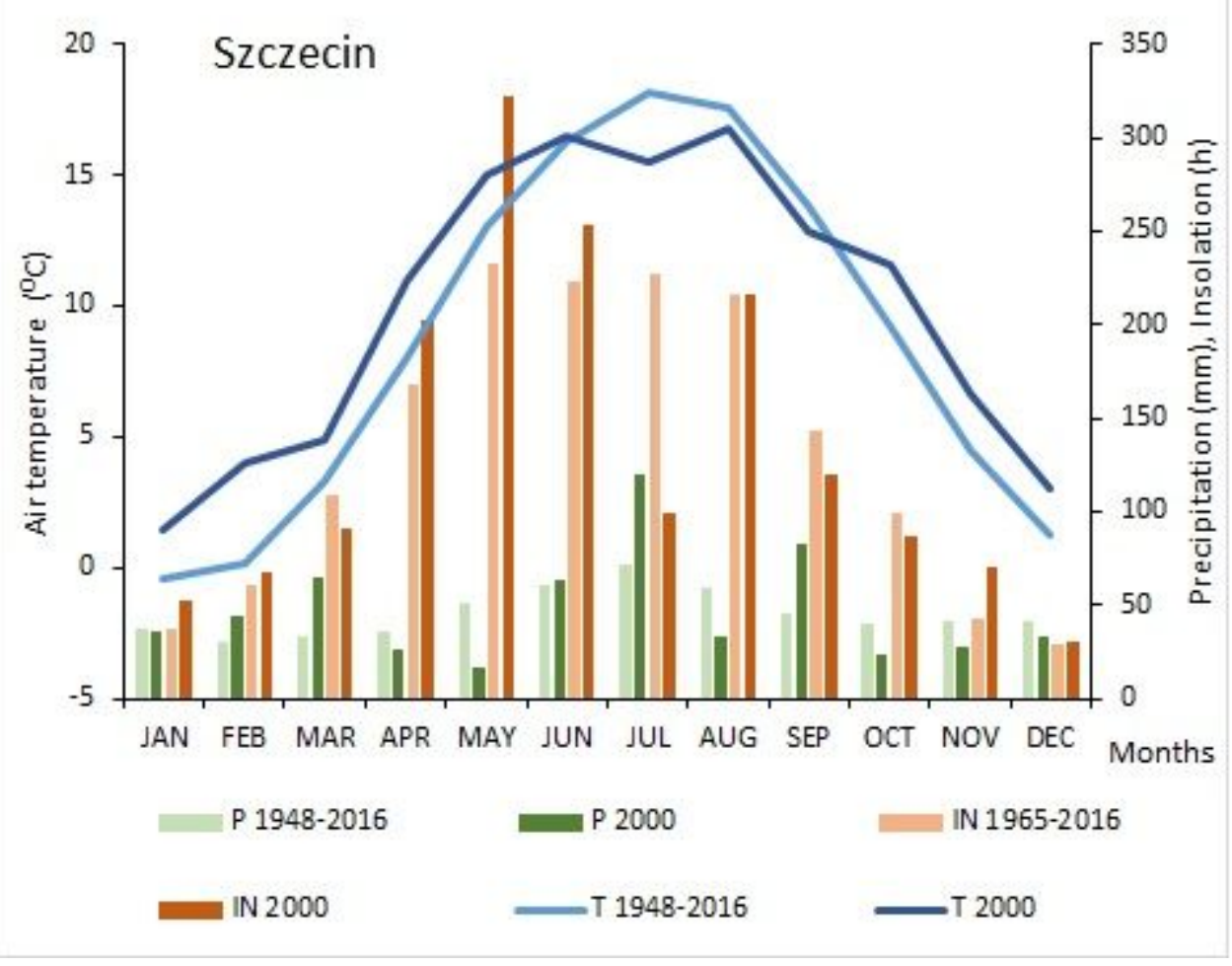

Figure 4

Mean monthly air temperature $(T)$, monthly precipitation $(P)$, and monthly insolation (IN) in the year of the outbreak (2000) - dark blue, green and orange colour, compared with mean values for 1948-2016 (T, P) and 1965-2016 (IN) - bright blue, green and orange colour. 


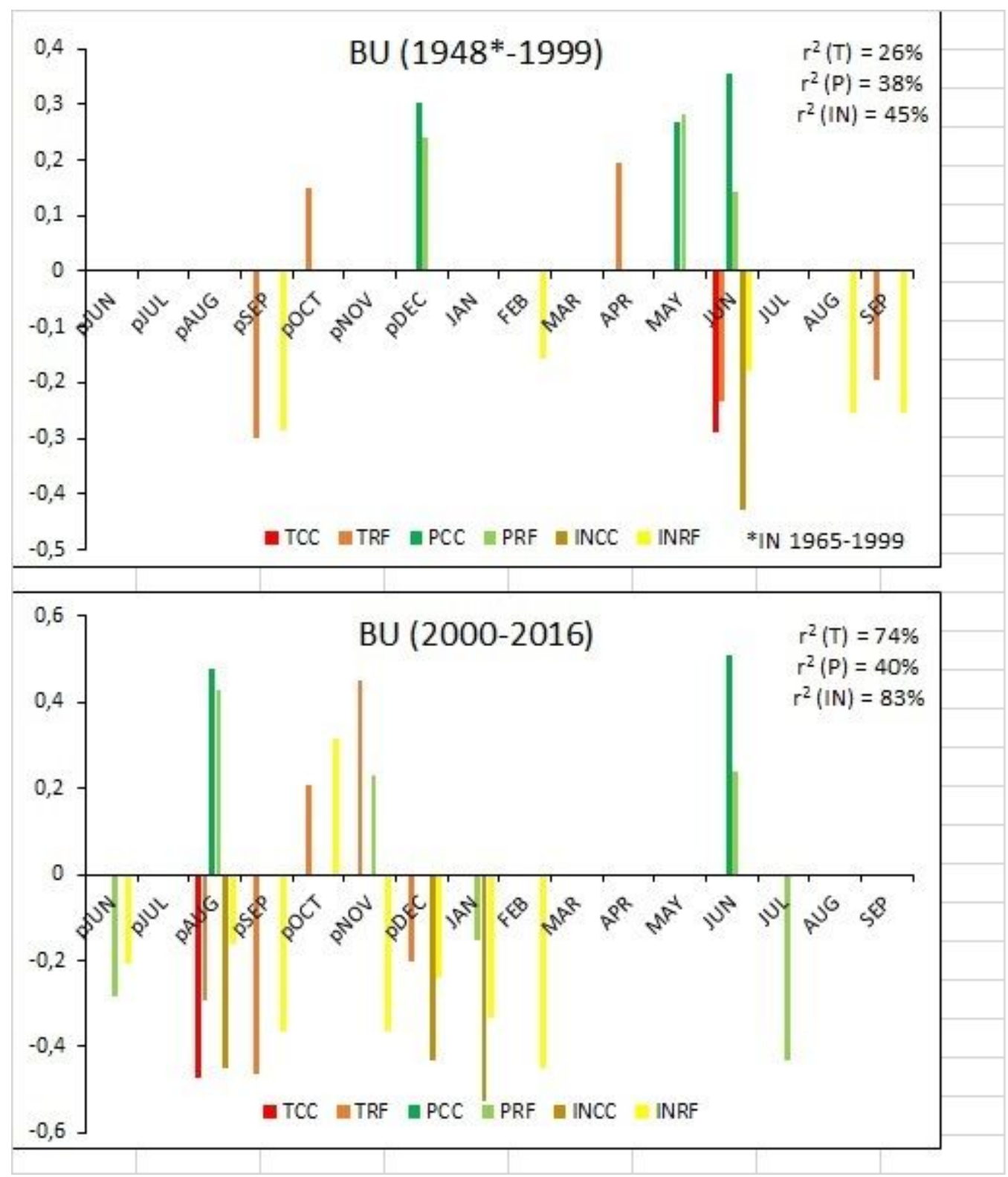

\section{Figure 5}

Results of correlation (CC) and response function (RF) analyses for the horse-chestnut chronology (BU) during the outbreak of Cameraria ohridella (2000-2016) for temperature $(T)$, precipitation $(P)$ and insolation (IN), and before the outbreak (T, P 1948-1999, *IN 1965-1999). Bars denote significant values ( $p$ $\leq 0.05)$; $p$, previous year. 